\title{
W

\section{Performance of three PCR methods targeting different regions of viral genome for the detection of TTV in Non A-E hepatitis, chronic B and C hepatitis and healthy blood donors}

\author{
Koray Ergunay ${ }^{1 *}$, Bulent Sivri ${ }^{2}$, Erdem Karabulut ${ }^{3}$, \\ Semsettin Ustacelebi ${ }^{1}$, Yusuf Bayraktar ${ }^{2}$ \\ 1 Department of Clinical Microbiology, Virology Unit, \\ Hacettepe University Faculty of Medicine, \\ Ankara, Turkey \\ 2 Department of Internal Medicine, Gastroenterology Division, \\ Hacettepe University Faculty of Medicine, \\ Ankara, Turkey \\ 3 Department of Biostatistics, \\ Hacettepe University Faculty of Medicine, \\ Ankara, Turkey
}

Received 5 July 2006; accepted 28 August 2006

\begin{abstract}
T T$ virus (TTV) was suggested to be the etiologic agent for non A-E hepatitis but this could not yet be proven due to high detection rates not only in hepatitis but also in healthy persons and sensitivity differences of PCR methods employed. The aim of this study was to evaluate TTV DNA positivity in non A-E hepatitis cases, chronic HBV and HCV hepatitis cases and healthy blood donors via PCR systems that target all regions of the viral genome used for viral detection. 23 non A-E hepatitis, 28 chronic HCV 21 chronic HBV cases and 56 healthy blood donors were included in the study and evaluated by PCR protocols that target 5'-UTR, 3'-UTR and N22 (ORF1) regions. As a result, 3'-UTR and 5'-UTR PCR had comparable detection rates that were higher than N22 PCR. Differences in detection rates among study groups were not statistically significant for any PCR method. Hepatic enzyme levels of the patients were not correlated with the presence of TTV DNA. Detection rate was significantly higher for Non A-E hepatitis group when positivity rates from all methods were combined. These results suggest an alteration of viral genotypes in Non A-E hepatitis which might be associated with pathogenesis.
\end{abstract}

(c) Versita Warsaw and Springer-Verlag Berlin Heidelberg. All rights reserved.

Keywords: TT virus, TTV, hepatitis B, hepatitis C, non A-E hepatitis

*E-mail: ekoray@hacettepe.edu.tr 


\section{Introduction}

TT virus or TorqueTeno Virus (TTV) is the first human circular single-stranded DNA virus, isolated from an idiopathic post transfusion hepatitis patient from Japan in 1997 by Representational Difference Analysis (RDA) (1). Polymerase Chain Reaction (PCR) remains to be the only means of TTV detection although certain serologic/molecular methods were developed but not yet used in large-scale studies [2]. TTV's close association with post transfusion hepatitis and fulminant hepatitis of unknown etiology suggested that the agent might be a candidate virus responsible for some cases of cryptogenic hepatitis. Many reports suggest TTV to be the causative agent for at least some cases of non A-E hepatitis [3-6]. After the extraordinarily divergent genetic heterogeneity displayed by the virus is identified, PCR methods targeting more conserved regions of the viral genome are developed. The use of these methods that can amplify a broader spectrum of viral genotypic variants showed that TTV infection is more frequent in both hepatitis cases and healthy populations than previously suggested, even raised questions about the pathogenic potential of the agent $[2,7,8]$. TT virus strains identified to date comprise 5 genogroups with at least 23 genotypes [9]. The region of the viral genome that should be targeted for genotyping is also a topic of debate [10].

PCR protocols for the detection of TTV that have been developed target either N22 region (in ORF1) which is reported to be sensitive to certain viral genotypes or UTR (untranslated) region in order to have increased specificity for more viral genotypes/subtypes compared to N22 region $[11,12]$. Although there have been numerable studies that focus on the detection of the virus, few used more than 1 primer set on both healthy subjects and cases of hepatic injury $[4,7,13]$. This study is designed so that three most widely-used and sensitive detection methods will be applied to a large number of subjects including healthy blood donors, non A-E hepatitis cases, chronic hepatitis $\mathrm{C}$ and hepatitis B cases.

\section{Statistical methods and experimental procedures}

\subsection{Study population}

23 patients admitted to Hacettepe University Hospital Department of Internal Medicine Gastroenterology Division with a diagnosis of Non A-E hepatitis were enrolled in the study. Other possible infectious, metabolic or toxic causes of hepatitis were ruled out by appropriate biochemical, serologic and molecular tests by gastroenterology specialists. 21 chronic hepatitis B and 28 chronic hepatitis C cases were evaluated along with Non A-E patients. 56 healthy persons qualified as blood donors by Hacettepe Hospital Blood Bank are also included in the study. All patients were included in the study with informed consent. The study was approved by Hacettepe University Medical Ethics Committee. Sera collected from all cases were aliquoted and stored at $-80^{\circ} \mathrm{C}$ until studied. 


\subsection{Detection of TTV DNA}

DNA was extracted from sera by using Viral DNA Extraction Kit ${ }^{\mathrm{TM}}$ (Metis Biotechnology, Turkey) and High Pure Viral Nucleic Acid Kit TM(Roche Diagnostics, Germany) according to manufacturers' instructions.

For PCR amplification of N22 region, degenerate primers were employed [15]. Primers for the first round were used for the $50 \mu \mathrm{l}$ mix containing $10 \mu \mathrm{l}$ of template, $2 \mathrm{mM}$ magnesium chloride, dNTPs and Taq polymerase. For the second PCR, inner set of primers was employed and magnesium chloride concentration was raised to $2.5 \mathrm{mM}$. 35 cycles of 30 seconds at $94^{\circ} \mathrm{C}$ were applied as the thermocycling conditions. 45 seconds at $60^{\circ} \mathrm{C}$, 45 seconds at $72^{\circ} \mathrm{C}$ after a denaturation step of 2 minutes at $94^{\circ} \mathrm{C}$ as the thermocycling conditions. A last polymerization step of 10 minutes at $72^{\circ} \mathrm{C}$ was also performed. Amplicons of 277 basepairs were separated by electrophoresis on $2 \%$ agarose gel, and visualized under ultraviolet light after staining with ethidium bromide.

A nested PCR protocol was used for targeting 3'-UTR [7]. Primers for the first round were used for a $50 \mu \mathrm{l}$ reaction mix containing $10 \mu \mathrm{l}$ of template, $2 \mathrm{mM}$ magnesium chloride, dNTPs and Taq polymerase. For the second PCR, inner set of primers was employed and magnesium chloride concentration was decreased to $1.75 \mathrm{mM}$. Thermocycling program consisted of 35 cycles of 30 seconds at $94^{\circ} \mathrm{C}, 45$ seconds at $55^{\circ} \mathrm{C}, 45$ seconds at $72^{\circ} \mathrm{C}$ after a denaturation step of 2 minutes at $94^{\circ} \mathrm{C}$ and a polymerization step of 10 minutes at $72^{\circ} \mathrm{C}$ at last. Amplicons of 243 basepairs were separated by electrophoresis on $2 \%$ agarose gel, and visualized under ultraviolet light after staining with ethidium bromide.

A single round PCR that targets 5'-UTR was used for detection viral DNA via this region [16]. A $50 \mu \mathrm{l}$ PCR mixture containing degenerate primers, $10 \mu \mathrm{l}$ of template, 2.5 mM magnesium chloride, dNTPs and Taq polymerase was amplified using a thermocycling program that consisted of an initial denaturation for 9 minutes at $95^{\circ} \mathrm{C}$; then 55 cycles of 20 seconds at $95^{\circ} \mathrm{C}, 20$ seconds at $55^{\circ} \mathrm{C}, 30$ seconds at $72^{\circ} \mathrm{C}$. Amplicons were also kept at $72^{\circ} \mathrm{C}$ for 5 minutes for further polymerization. PCR products were subjected to electrophoresis in 2\% agarose gel and the expected amplicons of 199 base pairs were investigated after staining with ethidium bromide under ultraviolet light.

Nucleic acid extraction, PCR amplification and electrophoresis were performed in seperate laboratories in order to avoid contamination. Positive and negative controls were employed for each reaction. If the initial reaction was negative, PCR was repeated. Sequences and genomic positions of the primers are provided in Table 1.

\subsection{Statistics}

Differences of descriptives and prevalences of TTV DNA positivity as determined by each PCR method were interpreted by statistical tests. $\mathrm{P}$ values $<0.05$ were assumed as statistically significant. Reliability of PCR tests was determined by Cronbach's alpha (Kuder-Richardson 20, KR20) coefficient and agreement between two PCR protocols were assessed by Kappa coefficient for each group. Data analyses were performed by SPSS ${ }^{\circledR}$ Version 12.0 . 
Table 1 Sequences, genomic positions and references of the primers used for the detection of TTV DNA.

\begin{tabular}{|c|c|c|c|c|c|}
\hline & $\begin{array}{l}\text { Target } \\
\text { region }\end{array}$ & Type & Sequence $^{a}$ and genomic position ${ }^{b}$ & $\begin{array}{c}\text { Product } \\
\text { Length }\end{array}$ & $\begin{array}{c}\text { Basic } \\
\text { Reference }\end{array}$ \\
\hline Protocol 1 & $\mathrm{~N} 22$ & Nested & $\begin{array}{l}\text { 1st round: } \\
C A G A C A G A G G A G A A G G C A A C A T G \\
\text { (sense, nt:1901-1923) } \\
\text { TACCAYTTAGCTCTCTATTCTWA } \\
\text { (antisense, nt:2228-2206) } \\
\text { 2nd round: } \\
\text { GGMAAYATGYTRTGGATAGACTGG } \\
\text { (sense, nt:1915-1938) } \\
\text { CTACCTCCTGGCATTTTACCA } \\
\text { (antisense, nt:2192-2171) }\end{array}$ & $277 \mathrm{bp}$ & 15 \\
\hline Protocol 2 & 3' - UTR & Nested & $\begin{array}{l}\text { 1st round: } \\
\text { GTGGGACTTTCACTTGTCGGTGTC } \\
\text { (sense, nt:3087-3110) } \\
\text { GACAAATGGCAAGAAGATAAAGGCC } \\
\text { (antisense, nt:3392-3368) } \\
\text { 2nd round: } \\
\text { AGGTCACTAAGCACTCCGAGCG } \\
\text { (sense, nt:3120-3141) } \\
\text { GCGAAGTCTGGCCCCACTCAC } \\
\text { (antisense, nt:3362-3342) }\end{array}$ & $243 \mathrm{bp}$ & 7 \\
\hline Protocol 3 & $5^{\prime}-\mathrm{UTR}$ & $\begin{array}{l}\text { Single } \\
\text { Round }\end{array}$ & $\begin{array}{l}\text { GCTACGTCACTAACCACGTG } \\
\text { (sense, nt: 6-25) } \\
\text { CTBCGGTGTGTAAACTCACC } \\
\text { (antisense, nt: 185-204) }\end{array}$ & $199 \mathrm{bp}$ & 16 \\
\hline
\end{tabular}

${ }^{a} \mathrm{~W}: \mathrm{A}$ or $\mathrm{T} ; \mathrm{M}: \mathrm{A}$ or $\mathrm{C}$; Y: C or T; R: A or G; B: G, C, or T);

${ }^{b}$ Genomic positions refer to TTV isolate TWH (GenBank accession NO: AB008394).

\section{Results}

Distribution of age and gender of the study groups and hepatic enzyme levels were summarized in Table 2. For patients belonging to hepatitis of unknown or known etiology groups, no statistical significant difference was detected between hepatic enzyme levels and TTV DNA positivity by any of the PCR methods ( $\mathrm{p}$ values not shown).

10 of 23 Non A-E hepatitis cases (43.5\%), 10 of 28 chronic hepatitis C cases (35.7\%), 4 of 21 chronic hepatitis B cases (19.1\%) and 17 of 56 blood donors $(30.4 \%)$ were found to be positive for TTV DNA by N22 PCR (Table 3). No statistically significant difference for TTV detection rates between study groups could be demonstrated.

15 of 23 Non A-E hepatitis cases (65.2\%), 14 of 28 chronic hepatitis C cases (50\%), 9 of 21 chronic hepatitis B cases $(42.9 \%)$ and 35 of 56 blood donors $(62.5 \%)$ were found to 
Table 2 Distribution of age, gender, aspartate aminotransferase (AST) and alanine aminotransferase (ALT) levels of the study groups.

\begin{tabular}{c|ccccc}
\hline Group & Number & $\begin{array}{c}\text { Gender } \\
(\text { Female /Male) }\end{array}$ & $\begin{array}{c}\text { Age (year) } \\
\left(\text { Mean } \pm \mathrm{SD}^{a}\right)\end{array}$ & $\begin{array}{c}\text { AST level (IU L } \\
\left(\text { Mean } \pm \mathrm{SD}^{1}\right)\end{array}$ & $\begin{array}{c}\text { ALT level (IU L } \\
\left(\mathrm{Mean}^{-1}\right)\end{array}$ \\
\hline \hline Non A-E Hepatitis & 23 & $15 / 8$ & $46.8 \pm 15.91$ & $52.0 \pm 46.16$ & $49.20 \pm 38.51$ \\
Chronic HCV Hepatitis & 28 & $16 / 12$ & $48.2 \pm 16.10$ & $49.46 \pm 34.50$ & $56.84 \pm 48.97$ \\
Chronic HBV Hepatitis & 21 & $11 / 10$ & $41.0 \pm 13.27$ & $46.77 \pm 28.48$ & $60.83 \pm 51.05$ \\
Healthy Blood Donors & 56 & $19 / 37$ & $32.4 \pm 8.1$ & n.d. $^{b}$ & n.d. $^{b}$ \\
\hline
\end{tabular}

a Standard Deviation;

${ }^{b}$ not determined.

Table 3 Detection rates of TTV DNA in study groups by different PCR methods.

\begin{tabular}{c|ccccccc}
\hline \multirow{2}{*}{ Group } & \multicolumn{7}{|c}{ TTV PCR } \\
& \multicolumn{2}{|c}{ Protocol 1 } & \multicolumn{2}{c}{ Protocol 2 } & \multicolumn{2}{c}{ Protocol 3 } \\
& Positive & Negative & Positive & Negative & Positive & Negative & Total \\
\hline \hline Non A-E Hepatitis & $10(43.5 \%)$ & $13(56.5 \%)$ & $15(65.2 \%)$ & $8(34.8 \%)$ & $13(56.5 \%)$ & $10(43.5 \%)$ & 23 \\
Chronic HCV Hepatitis & $10(35.7 \%)$ & $18(64.3 \%)$ & $14(50 \%)$ & $14(50 \%)$ & $13(46.4 \%)$ & $15(53.6 \%)$ & 28 \\
Chronic HBV Hepatitis & $4(19.1 \%)$ & $17(80.9 \%)$ & $9(42.9 \%)$ & $12(57.1 \%)$ & $9(42.9 \%)$ & $12(57.1 \%)$ & 21 \\
Healthy Blood Donors & $17(30.4 \%)$ & $39(69.6 \%)$ & $35(62.5 \%)$ & $21(37.5 \%)$ & $28(50 \%)$ & $28(50 \%)$ & 56 \\
\hline
\end{tabular}

be positive for TTV DNA by 3'-UTR PCR (Table 3). The difference of TTV detection rates between study groups were not statistically significant.

13 of 23 Non A-E hepatitis cases (56.5\%), 13 of 28 chronic hepatitis C cases (46.4\%), 9 of 21 chronic hepatitis B cases (42.9\%) and 28 of 56 blood donors (50\%) were found to be positive for TTV DNA by 5'-UTR PCR (Table 3). No statistically significant difference for TTV detection rates between study groups were demontrated.

In non A-E hepatitis group; 13.04\% (3 / 23) were positive and 4.34\% (1/23) were negative by all three PCR systems and $47.8 \%$ (11/ 23) gave positive results by two of PCR systems employed. For chronic C hepatitis group, 14.2\% (4 / 28) and 28.5\% (8/28) were positive and negative by all PCR systems respectively where $32.1 \%$ (9 / 28) were positive by two systems. $9.5 \%(2 / 21)$ and $42.8 \%$ (9/21) were positive and negative by all PCRs for chronic B hepatitis group respectively and simultaneous detection rate percentage by two of the systems used in the study was $28.5 \%(6 / 21)$. In healthy blood donors; $25 \%$ (14 / 56) were positive and 26.7\% (15 / 56) were negative by all three PCR systems. $17.8 \%(15 / 56)$ of this group gave positive results by two of PCR systems. Reliability analyses by Cronbach's alpha coefficient revealed low level of consistency of PCR tests for only blood donors. Agreement between PCR systems was below average for all groups as determined using Kappa coefficient.

If the positive detection rates from each group, regardless of the primer sets are interpreted, TTV DNA was detected in 22 of 23 Non A-E hepatitis cases (95.7\%), 20 of 28 chronic hepatitis C cases (71.4\%), 12 of 21 chronic hepatitis B cases (57.1\%) and 41 
of 56 blood donors $(73.2 \%$ ) (Table 4). This time, the detection rate for TTV DNA was found to be significantly higher for Non A-E hepatitis cases when compared to chronic C / B hepatitis groups and blood donors $(\mathrm{p}=0.031)$.

Table 4 Combined detection rates of TTV DNA in study groups.

\begin{tabular}{|c|c|c|c|}
\hline \multirow[b]{2}{*}{ Group } & \multicolumn{2}{|c|}{ TTV DNA } & \multirow[b]{2}{*}{ Total } \\
\hline & Positive & Negative & \\
\hline Non A-E Hepatitis & $22(95.7 \%)$ & $1(4.3 \%)$ & 23 \\
\hline Chronic HCV Hepatitis & $20(71.4 \%)$ & $8(28.6 \%)$ & 28 \\
\hline Chronic HBV Hepatitis & $12(57.1 \%)$ & $9(42.9 \%)$ & 21 \\
\hline Healthy Blood Donors & $41(73.2 \%)$ & $15(26.8 \%)$ & 56 \\
\hline
\end{tabular}

\section{Discussion}

Although TTV was initially shown to be associated with hepatitis of unknown etiology; identification of unusual genetic heterogeneity of the virus and very high detection rates in healthy people led to questioning of the pathogenic potential of the virus [2]. This work combines data obtained from three sensitive and widely-used PCR protocols for the detection of TTV from non A-E hepatitis cases, chronic B and C hepatitis cases and healthy blood donors.

In concordance with previous reports, our data from any of the PCR protocol does not indicate an increased detection of TTV, thus a possible etiologic role for hepatitis development in any of the groups studied (Table 3) [17-19]. This conclusion is also supported by similar levels of hepatic enzyme levels detected in patients with hepatitis. The PCR method that targets N22 region used in the study is based on probably the most commonly used method for TTV detection: a semi-nested PCR that uses NG059, NG061 and NG063 primers [3]; but with increased sensitivity for different subtypes of TTV owing to the degenerate bases $[15,30]$. TTV DNA positivity in $1.9 \%$ of blood donors and $19 \%$ in fulminant hepatic failure was reported with this primer set [15]. It is generally observed in initial studies that by using methods that target N22 region, prevalence of TTV infection in healthy subjects was below $15 \%$ and N22 PCR generally has a lower detection rate than UTR PCR due to its limited genotype specificity [11, 12]. Our data show that N22 PCR has indeed a lower detection rate, but we have a higher (30.4\%, Table 3) prevalence in healthy blood donors than expected. Biagini et al. noted that the use of degenerate primers and/or longer annealing and extension times increases detection rates of $\mathrm{N} 22 \mathrm{PCR}$, which supports our data and the use of degenerate primers for targeting N22 region [20].

PCR method that targets 3'-UTR in our study was reported to be one of the sensitive detection methods for TTV detection with a wide genotype range and used frequently in comparison studies $[7,12,20]$. Prevalence rates of non A-E hepatitis cases were reported 
to increase from $2.1 \%$ to $59.6 \%$ and increase from $12.8 \%$ to $39.6 \%$ was also noted for commercial blood donors with the utilization of these primers [7]. In our study, this protocol recognized TTV DNA in $65.2 \%$ and $62.5 \%$ of non A-E hepatitis patients and healthy blood donors respectively (Table 3 ).

By using the single step PCR method that targets 5'-UTR, a surprising increase in prevalence, from $23 \%$ to $92 \%$ was reported for blood donors in Japan [16] and from $11 \%$ to $51 \%$ for HCV infected subjects in Taiwan [21]. $49.5 \%$ positivity among blood donors could be detected in France with this set [20]. Here, we also report a very close prevalence 50\%, (Table 3) that would imply a similar distribution of the virus in our region in Turkey.

Previous studies that compare the performances of PCR methods targeting different regions of the viral genome reveal that the methods that detect 3'or 5'-UTR regions usually have comparable degrees of sensitivity $[11,12,20]$. In our study, prevalence rates observed for each group with 5' and 3'-UTR PCR were also similar and higher than N22 PCR (Table 3). It is also important to note that despite N22 PCR is considered to be less sensitive than UTR PCR; studies with cloned DNAs of specific TTV genotypes showed that different detection rates of these methods should be attributed to their specificities for different TTV genotypes, instead of sensitivities; N22 PCR having a narrow genotype range $[11,22]$. Many researchers also report that TTV may cause infections where more than one genotype can be detected simultaneously with different levels of viral loads, that can possibly influence viral DNA detection with various primer sets [9, 23, 24]. Although we did not perform DNA sequencing and phylogenetic analyses for our isolates due to high number of samples; our results with 3 primer sets clearly imply the genetic heterogeneity of TTV infection in our study groups.

TTV prevalence in Turkey must also be addressed and is known to vary according to study group and detection method employed. With PCR that targets N22 region detection rates ranging from $4.5 \%$ to $51.6 \%$ was reported for healthy adults and $2.5 \%$ for children [25-28].UTR PCR increases prevalence rates dramatically (as high as $82.7 \%$ ) as expected $[29,30]$. These data, besides differences in PCR methodology, probably imply the effect of genotype distribution from different parts of the country on detection rates. In eastern Anatolia, TTV genotypes 1-4 are frequently encountered with genotype 2 being the most prevalent [28]. Although a preferential detection of genotypes 1 and 2 was also reported [26], entire genotypic spectrum of Turkish TTV isolates and their distribution still awaits to be determined.

Our study revealed that, the sole presence of TTV cannot be suggested as a cause of hepatitis of unknown etiology. But there seems to be a difference of genotypic distribution of the virus, either causing liver injury or occurring as a consequence, in non A-E hepatitis cases. There are reports suggesting that TTV may be found in infected persons as quasispecies, and some undefined factors may alter the predominant genotype(s) [31, 32]. We have previously reported that for the results of non A-E patients from N22 and 3'-UTR PCR, there exists a statistically significant difference in distribution according to the primers used when compared to healthy blood donors ang chronic 
$\mathrm{HBV} / \mathrm{HCV}$ patients that indicates a different genotypic distribution in non A-E cases [33]. This hypothesis is also supported by our current results; which reveal an significant increase of viral detection when 3 sets of primers with different genotype sensitivities are combined (Table 4). The factor affecting the genotypic distribution may be at the same time triggering hepatic injury or in vivo genotypic change may be the factor for liver dysfunction. Certain genotypes of the virus may also be more pathogenic and infection with only these genotypes might cause tissue damage or related consequences as in the example of Human Papilloma Virus [22, 34]. Although genotype 1 was thought to be the candidate pathogenic subtype, based on the fact that studies which observe an increased detection rate of TTV in non A-E hepatitis commonly used N22 PCR protocols sensitive to this genotype; convincing data about this concept is still lacking $[3,4,6,34]$. Interactions among genotypes that result in enhancement of the pathogenicity of certain genotypes must also be considered [9].

Finally, for identifying exact role of TT virus in cases of hepatocellular dysfunction, detection of all existing viral genotypes must be detected and their distribution in study populations along with predominant genotypes in that geographic region need to be defined in future studies. Viral load detection for different genotypes will be of help when determining virologic dynamics of TTV infection.

\section{Acknowledgment}

Part of this study was supported by Hacettepe University Research Fund (Project NO: 0001 101010)

We are grateful to Dr. Serdar Tuncer and the staff of Metis Biotechnology, Turkey for providing 5'-UTR primers and for performing some of the PCR reactions with this primer set; and also to Irfan Atmaca, virology laboratory technician, for assistance in nucleic acid extraction and gel electrophoresis.

\section{References}

[1] T. Nishizawa, H. Okamoto, K. Konishi, H. Yoshizawa, Y. Miyakawa and M. Mayumi. "A novel DNA virus (TTV) associated with elevated transaminase levels in posttransfusion hepatitis of unknown etiology", Bioch. Biophys. Res. Commun., Vol. 241, (1997), pp. 92-97.

[2] M. Bendinelli, M. Pistello, F. Maggi, C. Fornai, G. Freer and M.L. Vatteroni. "Molecular properties, biology, and clinical implications of TT virus, a recently identified widespread infectious agent of humans", Clin. Microbiol. Rev., Vol. 14, (2001), pp. 98-113.

[3] H. Okamoto, T. Nishizawa, N. Kato, M. Ukita, H. Ikeda, H. Lizuka, Y. Miyakawa and M. Mayumi: "Molecular cloning and characterization of a novel DNA virus (TTV) associated with posttransfusion hepatitis of unknown etiology", Hepatol. Res., Vol. 10, (1998), pp. 1-16. 
[4] H. Ikeda, M. Takasu, K. Inoue, H. Okamoto, Y. Miyakawa and M. Mayumi: "Infection with an unenveloped DNA virus (TTV) in patients with acute or chronic liver disease of unknown etiology and in those positive for hepatitis C virus RNA", $J$. Hepatol., Vol. 30, (1999), pp. 205-212.

[5] R. Tuveri, F. Jaffredo, F. Lunel, B. Nalpa, S. Pol, C. Feray, P. Marcellin, V. Thibault, J.F. Delagneau, P. Opolon, B. Scarpa, C. Brechot and V. Thiers: "Impact of TT virus infection in acute and chronic, viral- and non viral-related liver diseases", $J$. Hepatol., Vol. 33, (2000), pp. 121-127.

[6] A. Sioda, M. Moriyama, H. Matsumura, M. Kaneko, N. Tanaka and Y. Arakawa: "Clinicopathological features of serum TTV DNA positive non A-G liver diseases in Japan", Hepatol. Res., Vol. 21, (2001), pp. 169-180.

[7] T.P. Leary, J.C. Erker, M.L. Chalmers, S.M. Desai and I.K. Mushahwar: "Improved detection systems for TT virus reveal high prevalence in humans, non-human primates and farm animals", J. Gen. Virol., Vol. 80, (1999), pp. 2115-2120.

[8] P. Biagini: "Human Circoviruses", Vet. Microbiol., Vol. 98, (2004), pp. 95-111.

[9] F. Maggi, E. Andreoli, L. Lanini, C. Fornai, M. Vatteroni, M. Pistello, S. Presciuttini and M. Bendinelli: "Relationships between Total Plasma Load of Torquetenovirus (TTV) and TTV Genogroups Carried", J. Clin. Microbiol., Vol. 43, (2005), pp. 4807-4810.

[10] P. Lemey, M. Salemi, L. Bassit and A.M. Vandamme: "Phylogenetic classification of TT virus groups based on the N22 region is unreliable", Virus. Res., Vol. 85, (2002), pp. $47-59$.

[11] H. Okamoto, M. Takahashi, T. Nishizawa, M. Ukita, M. Fukuda, F. Tsuda, Y. Miyakawa and M. Mayumi: "Marked Genomic Heterogeneity and Frequent Mixed Infection of TT Virus Demonstrated by PCR with Primers from Coding and Noncoding Regions", Virology, Vol. 259, (1999), pp. 428-436.

[12] P. Biagini, P. Gallian, H. Attoui, J.F. Cantaloube, M. Touinissi, P. de Micco and X. de Lamballerie: "Comparison of systems performance for TT virus detection using PCR primer sets located in non-coding and coding regions of the viral genome", $J$. Clin. Virol., Vol. 22, (2001), pp. 91-99.

[13] M. Mizokami, J.K. Albrecht, T. Kato, E. Orito and V.C.H. Lai: "TT virus infection in patients with chronic hepatitis $\mathrm{C}$ infection- effect of primers, prevalence, and clinical significance", J. Hepatol., Vol. 32, (2000), pp. 339-343.

[14] W.L. Irving, J.K. Ball, S. Berridge, R. Curran, A.M. Grabowska, C.L. Jameson, K.R. Neal, S.D. Ryder and B.J. Thomson: "TT virus infection in patients with hepatitis C: frequency, persistence, and sequence heterogeneity", J. Infect. Dis., Vol. 180, (1999), pp. 1750-1751.

[15] P. Simmonds, F. Davidson, C. Lycett C, L.E. Prescott, D.M. MacDonald, J. Ellender, P.L. Yap, C.A. Ludlam, G.H. Haydon, J. Gillon and L.M. Jarvis: "Detection of a novel DNA virus (TTV) in blood donor and blood products", Lancet, Vol. 352, (1998), pp. 191-195.

[16] K. Takahashi, H. Hoshino, Y. Ohta, N. Yoshida and S. Mishiro: "Very high prevalence 
of TT virus (TTV) infection in general population of Japan revealed by a new set of PCR primers", Hepatol. Res., Vol. 12, (1998), pp. 233-239.

[17] P. Fabris, M.R. Biasin, D. Infantolino, G. Tositti, E. Venza, A. Floreani, A. Zanetti and F. de Lalla: "TTV infection in patients with acute hepatitis of defined etiology and in acute non-A-E hepatitis", J. Hepatol., Vol. 32, (1999), pp. 661-665.

[18] M.C. Savas, C. Guney, A. Kadayifci, A. Balkan, M. Koruk, A. Kubar and A. Uygun: "High prevalence of transfusion-transmitted virus infection in patients with chronic liver diseases in an endemic area of hepatitis B and C virus", Med. Princ. Pract., Vol. 12, (2003), pp. 176-179.

[19] K. Das, P. Kar, R.K. Gupta and B.C.Das: "Role of transfusion-transmitted virus in acute viral hepatitis and fulminant hepatic failure of unknown etiology", J. Gastroenterol. Hepatol., Vol. 19, (2004), pp. 406-412.

[20] P. Biagini, P. Gallian, M. Touinssi, J.F. Cantaloube, J.P. Zapitelli, X. de Lamballerie and P. de Micco: "High prevalence of TT virus infection in French blood donors revealed by the use of three PCR systems", Transfusion., Vol. 40, (2000), pp. 590595.

[21] C.Y. Dai, M.L. Yu, Z.Y. Lin, S.C. Chen, M.Y. Hsieh, L.P. Lee, N.J. Hou, M.Y. Hsieh, L.Y. Wang, J.F. Tsai, W.L. Chuang and W.Y. Chang: "Clinical significance of TT virus (TTV) infection in chronic hepatitis $\mathrm{C}$ patients with high dose interferon-alpha therapy in Taiwan: reevaluated by using new set of TTV primers", Hepatol. Res., Vol. 27, (2003), pp. 95-100.

[22] H. Okamoto, T. Nishizawa and M. Ukita: "A novel unenveloped DNA virus (TT virus) associated with acute and chronic Non A-G hepatitis", Intervirogy, Vol. 42, (1999), pp. 196-204.

[23] J.K. Ball, R. Curran, S. Berridge, A.M. Grabowska, C.L. Jameson, B.J. Thomson, W.L. Irwing and P.M. Sharp: "TT virus sequence heterogeneity in vivo: evidence for co-infention with multiple genetic types", J. Gen. Virol., Vol. 80, (1999), pp. 1759-1768.

[24] S. Takayama, S. Yamazaki, S. Matsuo and S. Sugii: "Multiple infection of TT virus (TTV) with different genotypes in Japanese hemophiliacs", Biochem. Biophy. Res. Com., Vol. 256, (1999), pp. 208-211.

[25] S. Tuncbilek, D. Coskun, F. Cetinkaya, N. Hizel and P. Tahtakılıc: "Istanbul'da kan donorlerinde TT virusu (TTV) prevalansinin arastirilmasi”, Flora, Vol. 4, (1999), pp. 273-277.

[26] S. Erensoy, A.A. Sayiner, S. Turkoglu, D. Canatan, U.S. Akarca, R. Sertoz, T. Ozacar, Y. Batur, S. Badur and A. Bilgic: "TT virus infection and genotype distribution in blood donors and a group of patients from Turkey", Infection, Vol. 30, (2002), pp. 299-302.

[27] E. Odemis, F. Gurakan, K. Ergunay, A. Yuce, H. Ozen and N. Kocak: "TTV infection in children with and without liver disease", Indian. J. Gastroenterol., Vol. 23, (2004), pp. 135-137.

[28] A. Kalkan, A. Ozdarendeli, Y. Bulut, Y. Saral, M. Ozden, N. Kelestimur and Z.A. 
Toraman: "Prevalence and genotypic distribution of hepatitis GB-C/HG and TT viruses in blood donors, mentally retarded children and four groups of patients in eastern Anatolia, Turkey", Jpn. J. Infect. Dis., Vol. 58, (2005), pp. 222-227.

[29] M. Yazici, M.R. Comert, R. Mas, C. Guney, E. Cinar and I.H. Kocar: "Transfusiontransmitted virus prevalence in subjects at high risk of sexually transmitted infection in Turkey", Clin. Microbiol. Infect., Vol. 8, (2002), pp. 363-367.

[30] E. Karisga, T. Sanlidag, S. Akcali, S. Keskin, E. Aktas, Z. Karakoc, M. Helvaci, G. Sozen and M. Kuzu: "Clinical significance of TT virus infection in children with chronic hepatitis B", Pediatr. Int., Vol. 47, (2005), pp. 300-304.

[31] T. Nishizawa, H. Okamoto, F. Tsuda, T. Aikawa, Y. Sugai, K. Konishi, Y. Akahane, M. Ukita, T. Tanaka, Y. Miyakawa and M. Mayumi: "Quasispecies of TT virus (TTV) with sequence divergence in hypervariable regions of the capsid protein in chronic TTV infection", J. Virol., Vol. 73, (1999), pp. 9604-9608.

[32] F.L. Saback, S.A. Gomes and C. Niel: "High frequency of mixed TT virus infections in healthy adults and children detected by a simplified heteroduplex mobility assay", J. Virol. Methods., Vol. 101, (2002), pp. 117-125.

[33] K. Ergunay, S. Ustacelebi, Y. Bayraktar and A. Gunalp. "Detection of TT virus DNA by nested-PCR method in non A-E hepatitis cases", Mikrobiyol. Bul., Vol. 39, (2005), pp. 53-62.

[34] K. Sugiyama, K. Goto, T. Ando, F. Mizutani, K. Terabe, T. Yokohama and Y. Wada: "TT virus infection in Japanese children: isolates from genotype 1 are overrepresented in patients with hepatic dysfunction of unknown etiology", Tohoku. J. Exp. Med., Vol. 191, (2000), pp. 233-239. 